\title{
Transaction Costs and Farm-to-Market Linkages in China: Empirical Evidence from Apple Producers
}

\author{
Yu Wang ${ }^{1}$, Lu Han ${ }^{2}$, Kunda Qi ${ }^{1} \&$ Jianyun $\mathrm{Hou}^{3}$ \\ ${ }^{1}$ School of Economics and Management, Inner Mongolia University, Hohhot, China \\ ${ }^{2}$ Department of Liberal Arts, Texas A\&M University, College Station, TX, USA \\ ${ }^{3}$ School of Economics and Management, Northwest A\&F University, Yangling, China \\ Correspondence: Yu Wang, School of Economics and Management, Inner Mongolia University, Hohhot, China. \\ Tel: 86-0471-499-5765. E-mail: wy9230@163.com
}

Received: May 25, 2020

doi:10.5539/jas.v12n9p82
Accepted: July 13, 2020

Online Published: August 15, 2020

URL: https://doi.org/10.5539/jas.v12n9p82

\begin{abstract}
Using field surgveyed data from two apple production belts in China, this study estimates the impact of transaction costs on smallholders' market participation and integration. The analysis is based on an innovative measurement of the transaction costs and a disaggregated analysis of sales, information, negotiation, and monitoring costs. The results reveal that farmers' market participation levels are mainly determined by the proportional transaction costs and price, while their market integration depends on the fixed transaction costs and price. This suggests that, to lower the transaction costs and enable specialization and market participation, it is necessary to invest in and construct adequate farming infrastructure, update the rural information system, improve the structure of farmer households, and subsidize specialized rural cooperative organizations.
\end{abstract}

Keywords: market participation, market integration, transaction costs, China apple producers

\section{Introduction}

The development of agriculture continues to play a key role in the transformation of economies. Practically, fueled by economic development, increases in per capita income, changes in technology, and expansion of urbanization, China's agri-food markets are undergoing profound changes. Higher income forces mean greater demand for high-value commodities (Burciu \& Kicsi, 2016). However, agricultural commercialization puts increased emphasis on specialization, which is not confined to the production of high-value crops (such as apples, the dominant type of horticultural products in China). Such transformation is often accompanied by diversification of smallholder farming toward high-value activities linked to modern markets. At the same time, both commercialization and commercialization of smallholder agriculture in developing markets faces challenges, including information barriers, high transaction costs, and high market fees. In addition, rapidly changing markets create new challenges for the sub-sector. Sanitary and phytosanitary standards in the global market have already been tightened while new standards are being applied to address previously unknown and unregulated risks, especially in markets for high-value products. Meeting these standards represents potential barriers, especially to small producers and their market intermediary organizations seeking to expand their trade opportunities in the local or global markets. Policy interventions therefore require a clear understanding of how smallholders are affected by transaction costs and what institutional arrangements can enhance opportunities.

In China, supply chain integration is becoming a major strategy for guaranteeing fresh and perishable products to urban market outlets (Xu \& Long, 2020). Local farmers use different mechanisms and procedures for delivering agricultural products to markets, giving rise to a wide variety of supply chain arrangements. Some retailers are developing preferred-supplier arrangements with local growers, while others still purchase their products from dedicated wholesalers at the local and regional market. The choice between these different procurement strategies critically depends on differences in competitive relationships and consumer demands, which lead to a structure of transaction costs perceived in the local market (Zant, 2018).

On the production side, apple producers in China can choose to sell all, a portion, or none of their produce at the farm-gate, or local or global markets. To the best of our knowledge, little research in economics has been conducted on the factors affecting the farmers' market integration in China (Hou, Huo, \& Yin, 2019). One 
explanation for an apple producer's choice of marketing channel(s) may be the transaction costs that alternative outlets impose on sales. Many farmer households do not participate in certain agricultural markets due to the existence of transaction costs. Although the literatures clearly prove that high transaction costs can deter smallholders from entering more specialized, but at the same time, more profitable agricultural markets, there is a lack of empirical evidence on how market integration may polarize a small farmer economy (Escobal \& Cavero, 2012). Moreover, the relationship between these costs and marketing strategies has received little attention. Another important criticism of the literature on transaction costs is that theoretical development has not been accompanied by successful measurement of such costs. The current research adopts a transaction cost economics (TCE) framework and identifies how smallholders are affected by transaction costs and which institutional arrangements can enhance opportunities regarding farm-to-market linkages in China.

The rest of this paper is structured as follows. Section 2 presents a brief overview of literature on transaction costs and institutional arrangements. Section 3 reports the theoretical model and hypotheses to be tested. Section 4 discusses the empirical results, followed by conclusions and policy applications.

\section{Literature Review}

According to the seminal work of Coase (Carter \& Hodgson, 2006), transaction costs can be defined as a trade-off between the costs of coordination within a transacting organization and forming contracts in the market. Furthermore, TCE suggests that agents make costly decisions on various types of transactions due to transaction costs associated with information, monitoring, coordination, and enforcement of contracts. These intermediary firms economize on such costs, such as smallholders choosing in which markets to sell particular agricultural output. This depends not only on the price they expect to receive but also on extra fees related to transacting in these markets.

Transaction costs are divided into proportional and fixed costs (Filomena \& Lejeune, 2014). The proportional transaction costs include every-unit costs of participating in markets related to transportation costs, asymmetric information, and bargaining power. The fixed transactions costs are independent of the quantity of a transacted good. They include the costs of information, bargaining, and monitoring costs. Information costs are incurred before the trade takes place and consist of the cost of searching for higher prices and seeking potential buyers. Negotiation costs occur during the trade, such as during negotiating a contract, concluding an agreement, and making arrangements for settlement. Generally, to what extent a farmer can lower these transaction costs is usually decided by individual characteristics (education, skill, and gender), output attributes, and the relationship between agents participating in the market. Finally, supervision costs are incurred to make sure that the trade conditions are met (Zanello, Srinivasan, \& Shankar, 2014).

As transaction costs are an effective explanation for farmers' choice of marketing channels or type of contracting arrangements, a significant body of literature has been devoted to agricultural markets (Alinaghi, 2019). The application of the transaction costs approach to inform action is not limited to crop choice, but also the choice of livestock marketing channels (Leger-Bosch, 2019). The study revealed that some transaction costs variables (e.g., grade uncertainty, risk of not selling, time spent at the auction) were the significant factors affecting the choice of either live-ring auction or direct-to packer sales. Various factors affect the choice of the market channel, but the study found that problems of transport, searching for markets, and education level tend to have greater influence (Dimitri \& Gardner, 2019).

Another line of research focuses on the relationship between transaction costs and contract choices. Someone considers the socioeconomic characteristics of sellers and buyers, economic and technical characteristics of the commodity, as well as the institutional environment (Negi, Birthal, Roy, \& Khan, 2018). The author develops a non-linear programming model for individual firms' supply chain decisions and provides a framework for the application of the TCE to analyze policy interventions in developing markets. Recently, some interesting studies have focused on various contractual arrangements of cashew, tea, apple, and pear producers' contract choices employing different frameworks in transition economies (Escobal \& Cavero, 2012).

In contrast, we are interested in exploring the relationships between price and transaction costs in various marketing strategies in more profitable agricultural markets. Using a database of 635 Chinese apple producers, this study focuses on several determinants of farmer households, providing empirical evidence on what circumstances market integration may function under.

\section{Apple Production in Chinese Agro-economy}

As the dominant perennial horticultural crop, apples play a pivotal role in Chinese farmers' income increase and agriculture transition (Hou, Huo, \& Yin, 2017). The crop contributes to poverty reduction and trade balance and 
provides raw materials for agro-industries. The locations of the apple planting areas are shown in Figure 1. These districts are distributed north of the Yellow River and grouped into two broad belts, known as the Bohai Rim (including Liaoning, Shandong, and Hebei) and Loess Plateau (including Henan, Shanxi, Shaanxi, and Gansu). These provinces are endowed with a generally favorable climate for apple production, but they differ in the intensity and orchard model of apples produced, agro-ecological characteristics, and accessibility. The regions contain different agro-ecological zones that indicate the cultivation mode and type of apples that can be produced in accordance with the local altitude and climate. The Bohai Rim Belt is located at a lower attitude with rich rainfall and mainly produces up-market-oriented type apples as well as apples for the export market. The Loess Plateau is located at a higher attitude with less rainfall and produces processed-market-oriented type apples as well as apples for the domestic market.

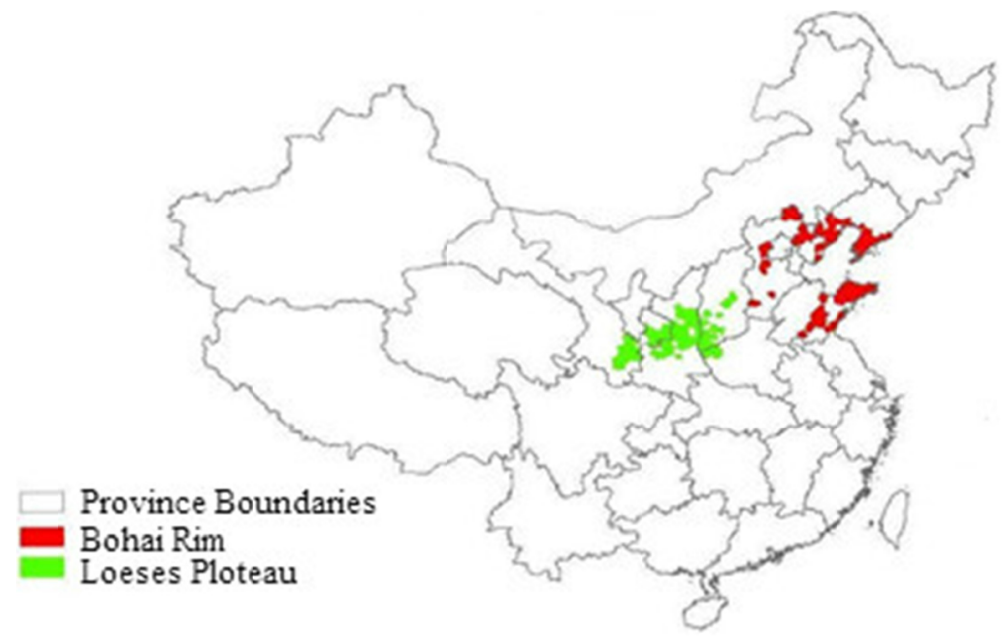

Figure 1. Apple planting belts of China

Source: The Ministry of Agriculture of the People's Republic of China.

In terms of proximity to the harbor and mega-city clusters, the Bohai Rim is much closer to the Dalian-Beijing-Tianjin-Tangshan-Qingdao Urban Agglomeration and Shandong Peninsula Urban Agglomeration, which offer a large upscale market for domestically consumed apples owing to their large and rapidly increasing higher income population. Furthermore, most apples for export are packaged and shipped from the harbors at Tianjin and Qingdao.

Since 1978, the ratio of apple planting areas in China has experienced three stages: 1978-1989, 1990-1997, 1998-present (Figure 2). Particularly, in 1982-1989 and 1991-1996, cultivated areas in both the Bohai Rim and Loess Plateau maintained rapid growth. After 2008, apple planting began to expand westward and northward. In 2018, China contributed over half of the global apple production and is forecast to produce 27.52 million MT in 2019. Overall, the apple planting area reached 2.31 million hectare in 2019. In the two belts, Shaanxi, Shandong, Henan, Hebei, Shanxi, and Liaoning contribute $88.2 \%$ of the total apple production in China (Table 1). Of the total yield of apple production, Shandong accounts for $21.46 \%$, Liaoning for $7.72 \%$, Hebei for $9.69 \%$, Henan $9.81 \%$, Shaanxi for $26.80 \%$, Shanxi for $8.25 \%$, and Gansu for $8.17 \%$ (Table 1). Accordingly, the ranking of average yields per hectare is Shandong (26.9 tons ha $\left.{ }^{-1}\right)$, Henan (20.4 tons ha $\left.{ }^{-1}\right)$, Shanxi (16.2 tons ha $\left.{ }^{-1}\right)$, Liaoning (15.9 tons ha ${ }^{-1}$ ), Shaanxi (14.2 tons ha ${ }^{-1}$ ), Hebei (10.8 tons ha ${ }^{-1}$ ), and Gansu (6.9 tons ha ${ }^{-1}$ ) (Figure 2). As apples are predominantly produced by smallholder farmers, this study focuses on this type of producer. About $98 \%$ of the apples produced are consumed in the domestic market, while the remainder are exported. Despite its overall minority share of production for export, the sub-sector earns the country significant amounts of foreign exchange in agriculture (Figure 3). 
Table 1. China's apple production (2012-2014)

\begin{tabular}{|c|c|c|c|c|c|c|}
\hline \multirow[b]{2}{*}{ Region } & \multicolumn{2}{|c|}{2012} & \multicolumn{2}{|c|}{2013} & \multicolumn{2}{|c|}{$2014(\mathrm{~F})$} \\
\hline & $\begin{array}{l}\text { Yield } \\
\text { (million ton) }\end{array}$ & $\begin{array}{l}\text { Percentage } \\
(\%)\end{array}$ & $\begin{array}{l}\text { Yield } \\
\text { (million ton) }\end{array}$ & $\begin{array}{l}\text { Percentage } \\
(\%)\end{array}$ & $\begin{array}{l}\text { Yield } \\
\text { (million ton) }\end{array}$ & $\begin{array}{l}\text { Percentage } \\
(\%)\end{array}$ \\
\hline China & 33.70 & 100.00 & 31.70 & 100.00 & 27.52 & 100.00 \\
\hline Shaanxi & 9.10 & 27.40 & 8.20 & 25.80 & 7.37 & 26.80 \\
\hline Shandong & 7.40 & 22.30 & 6.88 & 21.70 & 5.90 & 21.46 \\
\hline Henan & 2.97 & 8.90 & 2.86 & 9.00 & 2.70 & 9.81 \\
\hline Hebei & 3.10 & 8.40 & 2.90 & 9.20 & 2.66 & 9.69 \\
\hline Shanxi & 2.60 & 7.80 & 2.30 & 7.30 & 2.27 & 8.25 \\
\hline Gansu & 2.50 & 7.50 & 2.30 & 7.30 & 2.25 & 8.17 \\
\hline Liaoning & 240.00 & 7.20 & 250.00 & 7.90 & 212.46 & 7.72 \\
\hline
\end{tabular}

Source: The Ministry of Agriculture of the People's Republic of China (http://www.gov.cn).

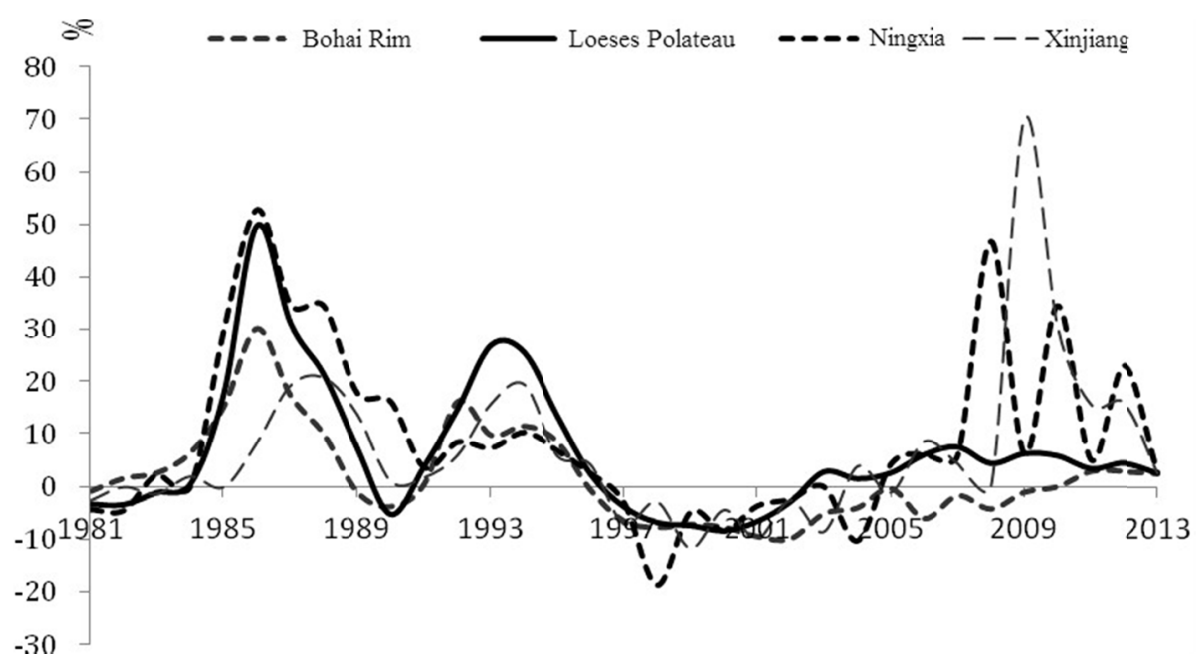

Figure 2. Apple planting trend by area

Source: China Agriculture Statistical Yearbook (1982-2014).

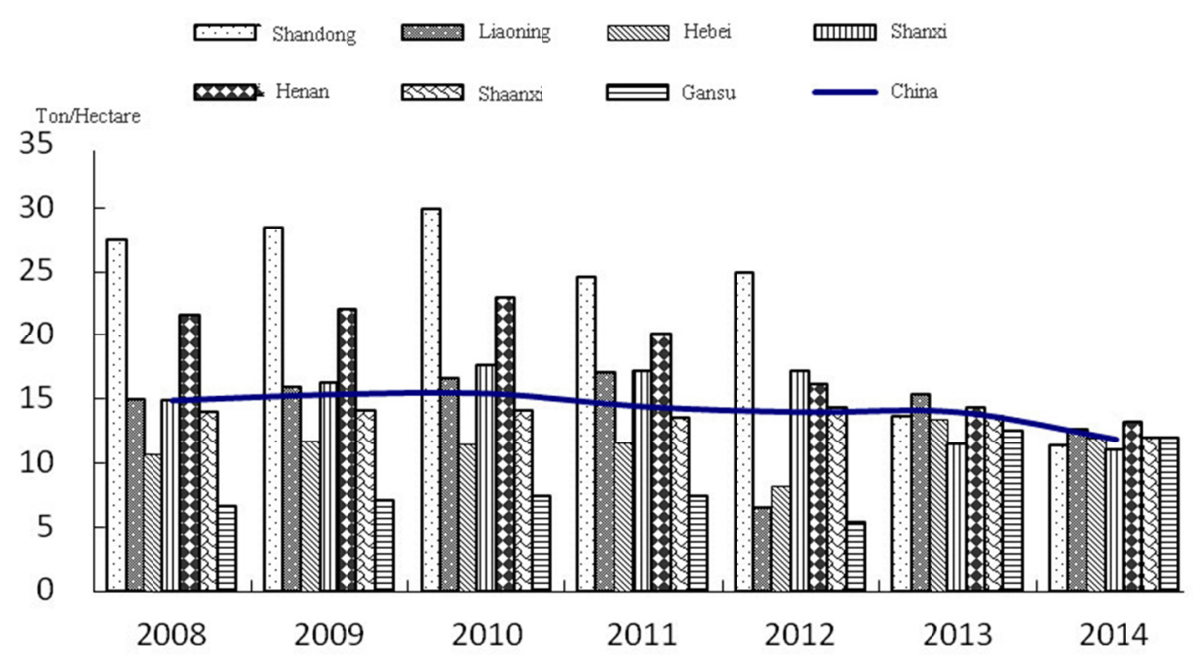

Figure 3. Apple yields per hectare of seven main provinces (2009-2014)

Source: China Agriculture Statistical Yearbook. 


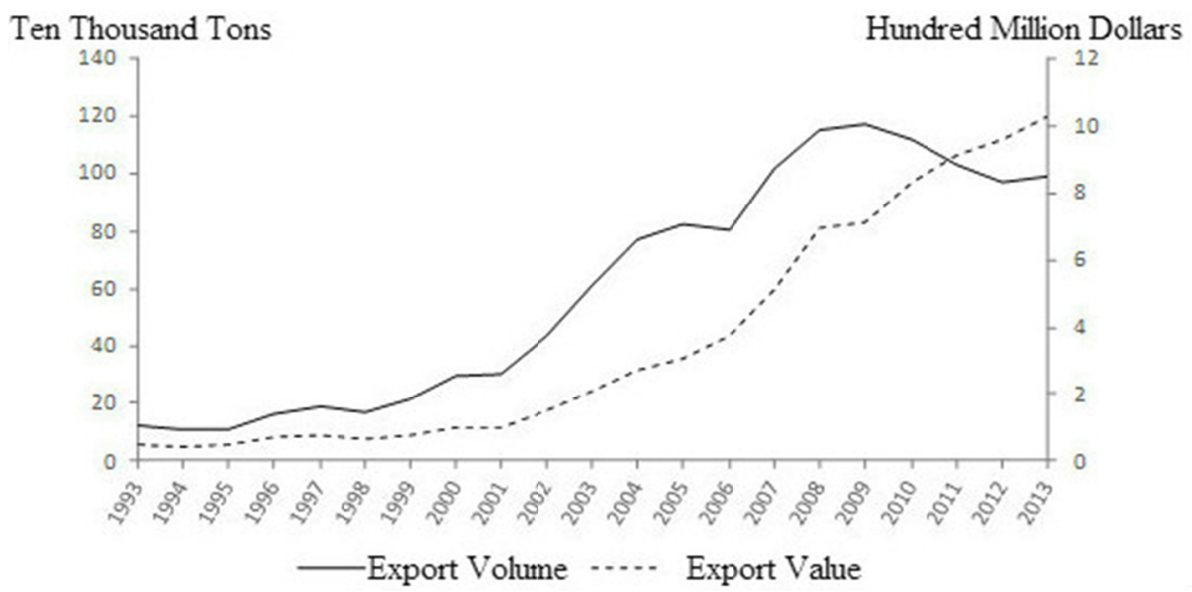

Figure 4. Trends of the apple exports

Source: FAO (2014).

\section{Sampling Method and Statistical Description}

\subsection{Sampling Method}

The current study used a field survey conducted by the China Agriculture Research System (CARS) during the 2012/13 cropping season as part of a project to assess the economic impact of apple production. The survey was conducted in the two apple planting belts in Bohai Rim (Liaoning, Hebei, and Shandong) and Loess Plateau (Henan, Shanxi, Shaanxi, and Gansu). These selected provinces represent approximately $92 \%$ of the smallholders that produce apples for domestic and foreign markets. The location of these provinces is shown in Figure 1.

A multi-stage sampling procedure was used to select counties, sub-divisions, and small-scale producers. The first stage was the deliberate selection of 122 counties in the seven selected provinces mentioned above. To ensure all apple producers were included in the sample, the probability proportional to size sampling method was used. Overall, 14 counties were randomly selected in the seven provinces and 635 apple producer households were selected for interview (Table 2). Detailed information on apple production and transaction costs was collected via face-to-face questionnaire interview.

Table 2. Sample distribution

\begin{tabular}{llllllll}
\hline Province & Henan & Shandong & Liaoning & Hebei & Shaanxi & Gansu & Shanxi \\
\hline Sample Size & 91 & 90 & 91 & 91 & 91 & 89 & 92 \\
Percentage (\%) & 14.33 & 14.17 & 14.33 & 14.33 & 14.33 & 14.01 & 14.49 \\
\hline
\end{tabular}

Source: Field survey.

Household characteristics are reported in Table 3. Particularly, as one of the important household characteristics, membership of an institution may help smallholders to facilitate market integration and lower transaction costs. We consider one membership, "Producers' Cooperative Organization"; $40 \%$ of all households are members of such an organization, which provide them with technical training, information service, and input factors for buying and selling apples. 
Table 3. Apple producer household characteristics

\begin{tabular}{|c|c|c|c|c|}
\hline Variable & Variable Description & Measurement & Frequency & Percentage $(\%)$ \\
\hline \multirow{3}{*}{ PLOTSIZE } & \multirow{3}{*}{ Total land size for apple production } & $\leq 0.5$ ha & 350 & 55 \\
\hline & & $0.5-1$ ha & 216 & 34 \\
\hline & & $>1$ ha & 69 & 11 \\
\hline \multirow{3}{*}{ AGE } & \multirow{3}{*}{ Average age of householders } & $\leq 40$ years & 69 & 10.87 \\
\hline & & $40-60$ years & 445 & 70.08 \\
\hline & & $>60$ years & 121 & 19.06 \\
\hline \multirow{5}{*}{ EDU } & \multirow{5}{*}{ Final education level of householders } & None & 14 & 2.2 \\
\hline & & Initial & 113 & 17.8 \\
\hline & & Primary & 353 & 55.59 \\
\hline & & Secondary & 150 & 23.62 \\
\hline & & Higher & 5 & 0.79 \\
\hline \multirow{3}{*}{ LABOR } & \multirow{3}{*}{ Number of adults engaged in farming } & $\leq 2$ & 46 & 7.24 \\
\hline & & $2-4$ & 547 & 86.14 \\
\hline & & $>4$ & 42 & 6.61 \\
\hline \multirow[t]{2}{*}{ MEMBER } & Member of rural cooperative organization & Yes $=1$ & 254 & 40 \\
\hline & & $\leq 10$ & 49 & 7.72 \\
\hline \multirow[t]{2}{*}{ YEAR } & Years of experience of apple production & $10-20$ & 309 & 48.66 \\
\hline & & $>15$ & 277 & 43.62 \\
\hline
\end{tabular}

Source: Field survey.

\subsection{Statistical Description}

The smallholders (defined as farmers with $\leq 1$ ha land.) dominate apple production in China (Table 3). Therefore, this organization structure is characterized by small production volumes of variable quality, which reflect limited access to inputs and finance, low level of investment, and limited access to agricultural technologies and practices. Inadequate infrastructure, high costs of storage and transportation, and over-competitive markets also militate against the production of marketable surplus. Therefore, smallholders' market participation is typically a constrained choice, and such a choice critically depends on their ability and willingness to participate in input and output markets and on the functionality of the markets they are able to access. As sellers of apple, they likely to increase their engagement in markets when well-functioning markets give them appropriate incentives; they have access to and the ability to use assets productively, and efficient infrastructure allows them to transport their product to the market at reasonable cost. As apples are a highly commercial crop, producers become more commercially oriented and participation in the processes of value chain development is facilitated, which may require support to assistant producers in meeting more rigorous standards, or engaging in more complex contractual arrangements.

Apple producers are able to choose to sell their output at farm-gate markets, or in local and distant markets. Local markets are usually situated in the central town of high potential counties, and the country's central and largest logistic and wholesale markets are located in the largest cities, such as Beijing, Shanghai, Guangzhou, Chongqing and Xi'an. In general, apple producers will receive higher prices but face more transportation difficulties at regional and distant markets (Table 4). The transportation distance by individual farmers to reach markets varies from 0 to $1753 \mathrm{~km}$ and is diversified based on specific household characteristics.

Table 4. Market price, quantity, and transportation

\begin{tabular}{|c|c|c|c|c|}
\hline \multicolumn{2}{|l|}{ Market } & Farm-gate Market & Regional Market & Distant Market \\
\hline \multicolumn{2}{|l|}{ Number of household transactions } & 387 & 220 & 28 \\
\hline \multirow{3}{*}{ Average Price (yuan/kg) } & Premium Grade & 5.16 & 5.46 & 6.4 \\
\hline & First Grade & 4.32 & 4.36 & 4.5 \\
\hline & Second Grade & 2.52 & 2.8 & 3.6 \\
\hline \multicolumn{2}{|c|}{ Average Market distance $(\mathrm{km})$} & 0.85 & 7.58 & 118 \\
\hline \multicolumn{2}{|c|}{ Average Levels of transportation Difficulties ( $1=$ very easy; $5=$ very difficult $)$} & 1.01 & 1.18 & 3.71 \\
\hline
\end{tabular}

Source: Field survey. 


\section{Theoretical and Empirical Model}

Following Key et al. (2000), we incorporate the transaction costs into the farmer household model framework. The farmers' market participation can be conveniently specified as a choice model. In addition to deciding how much of each output $i$ to consume $\left(c_{i}\right)$, produce $\left(q_{i}\right)$ and use of input $\left(x_{i}\right)$, the household also decides how much of each agricultural output to sell $\left(m_{i}\right)$. When the farmer household sells the output, $m_{i}>0$. When the household purchases such output, $m_{i}<0$. If we suppose that there were no transaction costs, the household's problem would be to maximize the utility Equation (1) subject to (2)-(5), which represent the cash constraint, the resource balance, production technology, and non-negativity condition, respectively.

$$
\max u=u\left(c ; z_{u}\right)
$$

Subject to,

$$
\begin{gathered}
\sum_{i=1}^{N} p_{i}^{m} m_{i}+T=0 \\
q_{i}-x_{i}+A_{i}-m_{i}-c_{i}=0, i=1, \ldots, N \\
G\left(q, x ; z_{q}\right)=0 \\
c_{i}, q_{i}, x_{i} \geq 0
\end{gathered}
$$

where, $p_{i}^{m}$ the market price of output $i, A_{i}$ is endowment in good $i, T$ is exogenous transfers and other incomes, $z_{u}$ and $z_{q}$ are exogenous shifters in utility and production, respectively, and $G$ represents the production technology.

The cash constraint (2) states that expenditures on all purchases must not exceed revenues from all sales and transfers. The resource balance (3) states that, for each of the $N$ goods, the amount consumed, used as input, and sold is equal to what is produced and bought plus the endowment of the good. The production technology (4) relates inputs (e.g., land, labor, and other input factors) to outputs. Proportional transaction costs (PTCs) raise the price paid by a buyer and lower the price received by a seller and these costs may include transportation and marketing costs (Key et al., 2000). However, the fixed transaction costs (FTCs) are invariant to the quantity transacted; hence, they are generally unobservable though factors $z_{u}$ and $z_{q}$ with coefficients $\delta_{i}^{s}$ and $\delta_{i}^{b}$, respectively. Incorporating both the FTCs and the PTCs into the cash constraint of a farmer household, it can then be expressed as:

$$
\left.\left.\left.\sum_{i=1}^{N}\left[\left(p_{i}^{m}-v c_{i}^{s}\left(z^{s}\right)\right) \delta_{i}^{s}+\left(p_{i}^{m}+v c_{i}^{b}\left(z^{b}\right)\right) \delta_{i}^{b}\right)\right] m_{i}-f c_{i}^{s}\left(z^{s}\right)\right) \delta_{i}^{s}-f c_{i}^{b}\left(z^{b}\right)\right) \delta_{i}^{b}+T=0
$$

where, the household pays the fixed transaction $\operatorname{cost} f c_{i}^{s}$ and variable transaction $\operatorname{costs} v c_{i}^{s}$ if it sells good $i$ and pays $f c_{i}^{b}$ and $v c_{i}^{b}$ it buys good $i$. To solve the household utility problem, a Lagrange expression can be derived and first-order conditions (FOC) for the consumption goods obtained from Equations (1)-(6).

$$
\begin{aligned}
L & =u\left(c ; z_{u}\right)+\sum_{i=1}^{N} \mu_{i}\left(q_{i}-x_{i}+A_{i}-m_{i}-c_{i}\right)+\phi G\left(q, x ; z_{q}\right) \\
& \left.\left.\left.+\lambda\left[\sum_{i=1}^{N}\left[\left(p_{i}^{m}-v c_{i}^{s}\left(z^{s}\right)\right) \delta_{i}^{s}+\left(p_{i}^{m}+v c_{i}^{b}\left(z^{b}\right)\right) \delta_{i}^{b}\right)\right] m_{i}-f c_{i}^{s}\left(z^{s}\right)\right) \delta_{i}^{s}-f c_{i}^{b}\left(z^{b}\right)\right) \delta_{i}^{b}+T\right]
\end{aligned}
$$

where, $\mu_{i}, \phi$ and $\lambda$ are the Lagrangian multipliers of resource balance, cash constraint, production technology. FOC of (7) can be written as:

$$
\begin{gathered}
\frac{\partial u}{\partial c_{i}}-\mu_{i}=0, i \in\left\{i \mid c_{i}>0\right\} \\
\mu_{i}+\phi \frac{\partial G}{\partial q_{i}}=0, i \in\left\{i \mid q_{i}>0\right\} \\
\mu_{i}+\phi \frac{\partial G}{\partial q_{i}}=0, i \in\left\{i \mid q_{i}>0\right\} \\
-\mu_{i}+\phi \frac{\partial G}{\partial x_{i}}=0, i \in\left\{i \mid x_{i}>0\right\} \\
\left.-\mu_{i}+\lambda\left[p_{i}^{m}-v c_{i}^{s}\left(z^{s}\right)\right) \delta_{i}^{s}+\left(p_{i}^{m}+v c_{i}^{b}\left(z^{b}\right)\right) \delta_{i}^{b}\right]=0, i \in\left\{i \mid m_{i} \neq 0\right\}
\end{gathered}
$$


The decision price $p_{i}$ is thus defined as:

$p_{i}=p_{i}^{m}-v c_{i}^{s}$ If $m_{i}>0$, for the selling household,

$p_{i}=p_{i}^{m}+v c_{i}^{b}$ If $m_{i}<0$, for the buying household,

$p_{i}=\tilde{p}_{i}=\mu_{i} / \lambda$ If $m_{i}=0$, for the self-sufficient household.

In the absence of the transaction costs, the supply curve would be $q\left(p_{m}, z_{q}\right)$. However, when the transaction costs are incorporated, the supply curves for the producers are:

$$
q=q\left(p^{m}-t c^{s}-f c^{s}, z_{q}\right)
$$

For empirical analysis, mostly focusing on the selling households, a linear expression is assumed for the supply equations and the PTCs as follows:

$$
q\left(p, z_{q}\right)=p \beta+z_{q} \beta_{q}
$$

This leads to linear expressions for supply by sellers as follows:

$$
q^{s^{*}}=p^{m} \beta_{m}+z_{t}^{s} \beta_{t}^{s}+z_{q} \beta_{q}
$$

where, $z_{t}$ are exogenous characteristics that affect transaction costs when selling, $z_{q}$ are production shifters, $z_{c}$ are consumption shifters and $\alpha_{q}^{s}, \alpha_{c}^{s}$ are their coefficients, and $\beta_{t}^{s}, \beta_{q}$ are coefficients of $z_{t}^{s}$ and $z_{q}$, respectively.

Therefore, the econometric model of the farmer household market participation can be obtained as:

$$
q^{s^{*}}=p^{m} \beta_{m}+z_{t}^{s} \beta_{t}^{s}+z_{q} \beta_{q}+u
$$

where, $\mu$ is an error term.

The final decision for the household is at which market to sell its output $q$. We focus on farm households who are net-suppliers. Then, $J$ available markets exist where a farm-household can sell $q_{i}$, and the farm-household's decision depends on three factors. Firstly, selling in market $j$ for a given transaction $i$ is associated with variable transaction costs $v c_{i j}^{s}$ per unit of product. These costs are a function of the market costs and the transportation costs. Secondly, the household considers the expected price $p_{i j}$ to be received on each candidate market $j$. Finally, selling on market $j$ is associated with FTCs $f c_{i j}{ }^{s}$, which are invariant to costs such as searching for potential buyers and obtaining information about prices, markets, or types of contractual agreements available at different markets.

Based on the above, for a given transaction $i$, a farm-household chooses to sell $q_{i}$ in the market $j_{i}$ that yields the highest net profits among the available candidate markets. This can be written in the semi-structural form as:

$$
j_{i}=\underset{k}{\arg \max }\left\{\Pi_{i}=\Pi\left(q_{i}, p_{i j}, f c_{i j}^{s}, v c_{i j}^{s}\right)\right\}
$$

where, $\Pi_{i}$ is the net profit function. We specify the econometric model of $\Pi_{i}$ as follows:

$$
\Pi_{i k}^{*}=\mathbf{X}_{i k} \beta+W_{i} \beta_{k}+\varepsilon_{i k}
$$

Let $j_{i}$ denote the market choice that maximizes profits for transaction $i$,

$$
j_{i}=\underset{k}{\arg \max }\left\{\prod_{i k}^{*}, k=1, \ldots, J\right\}
$$

Suppose that $\varepsilon_{i k}$ are distributed with type I extreme value distribution, the choice of market $j$ for transaction $i$ is given by:

$$
\operatorname{Pr}\left(j_{i}=j \mid \mathbf{X}_{i k}, W_{i}\right)=\frac{\exp \left(\mathbf{X}_{i k} \beta+W_{i} \beta_{j}\right)}{\sum_{k=1}^{J} \exp \left(\mathbf{X}_{i k} \beta+W_{i} \beta_{k}\right)}
$$

We divide the markets $J$ into three types: farm-gate market, regional market, and distant market. As shown in Figure 5, there are more barriers in the farm-gate market than in the local market, such as the inefficient rural infrastructure, higher transaction costs, inequitable and uncompetitive market relations, and lack of innovative institutions (Kisamba-Mugerwa, 2005). 


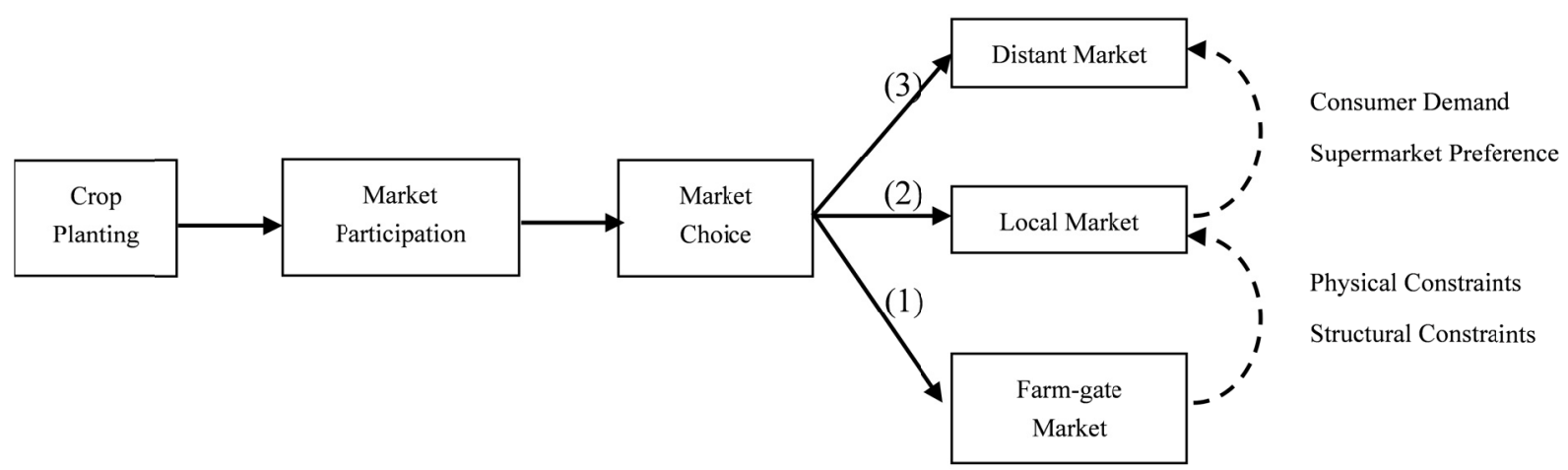

Figure 5. Three scenarios of apple producers' market choices

Similarly, the distant market, like regional and/or national markets, requires higher private grades, standards for food quality and safety, and the adoption of contracts between buyers and sellers at various points along the agri-food chain. Therefore, three types of markets are ordered reactions to farmer households.If considering the farm-gate, local, and distant markets as degrees of barriers to entry, we can formulate a discrete choice variable taking the values of 1,2 , and 3, respectively and determine the ordinal relevance. In scenario 3 , there are higher requirements for smallholders than in scenario 2 , which has higher requirements than scenario 1 . Therefore, when discrete choices have ordinal relevance, an ordered probit model may be the most appropriate specification (Sykuta, 2008). The ordered probit probabilities of choice among the farm-gate, local, and distant market are given by:

$$
\begin{aligned}
& \operatorname{Pr}(j=1)=\Phi\left(\mu_{\left.1-x_{i}^{\prime} \beta\right)}\right. \\
& \operatorname{Pr}(j=2)=\Phi\left(\mu_{2}-x_{i}^{\prime} \beta\right)-\Phi\left(\mu_{\left.1-x_{i}^{\prime} \beta\right)}\right. \\
& \operatorname{Pr}(j=3)=1-\Phi\left(\mu_{2}-x_{i}^{\prime} \beta\right)
\end{aligned}
$$

where, $\mu$ is a threshold parameter that is estimated with $\beta$. Mathematically, the marginal effects of the ordered probit model are given by:

$$
\begin{gathered}
\frac{\partial \operatorname{Pr}(j=1)}{\partial x_{k}}=-\beta_{k} \varphi\left(\mu_{1}-x_{i}^{\prime} \beta\right) \\
\frac{\partial \operatorname{Pr}(j=2)}{\partial x_{k}}=-\beta_{k}\left[\varphi\left(\mu_{2}-x_{i}^{\prime} \beta\right)-\varphi\left(\mu_{1}-x_{i}^{\prime} \beta\right)\right] \\
\frac{\partial \operatorname{Pr}(j=3)}{\partial x_{k}}=-\beta_{k} \varphi\left(\mu_{2}-x_{i}^{\prime} \beta\right)
\end{gathered}
$$

Assuming $\beta$ is positive, increasing one of the $x$ 's while holding the parameters constant effectively shifts the probability distribution to the right. In this research, the $\operatorname{Pr}(y=1)$ must decline and the $\operatorname{Pr}(y=3)$ must increase as the probability distribution shifts to the right. Thus, a positive value may be correctly interpreted as implying a positive relationship between the variables of interest and the probability of $y=3$ (distant market). However, because the relative mass of the distribution moving from $y=1$ to $y=3$, the net effect on $\operatorname{Pr}(y=2)$ is ambiguous and requires more detailed examination. Thus, a statistically significant positive value for $\beta$ is not sufficient to conclude that the probability of all higher outcomes increases.

\section{Econometric Results}

\subsection{Variable Description}

We identify the transaction costs as two categories, namely, the PTCs and the FTCs. The former is represented by sale costs, which include the costs of storage, packaging, and transportation, information symmetry, and bargaining power. The latter include information, negotiation, and enforcement costs. Information costs occurred before the trade while attempting to obtain the information about price and buyer. Negotiation costs are the costs of concluding an agreement. Enforcement costs are the costs to monitor the enforcement of the transaction. Further detailed descriptions are given below (Table 5). 
Table 5. Transaction costs related variables

\begin{tabular}{|c|c|c|c|}
\hline Variable Name & Variable Description & Measurement & Variable Property \\
\hline SALECOST & Sale cost & How much did you pay for storage, packaging, and transportation? & Ration variable \\
\hline \multirow{4}{*}{ MARKETPRICE } & \multirow{4}{*}{ Accuracy of other markets price } & Do you know the sale price at another two markets? & Ordinal variable $(1-3)$ \\
\hline & & Unclear & 1 \\
\hline & & Not so clear & 2 \\
\hline & & Very clear & 3 \\
\hline \multirow{4}{*}{ FAIRPRICE } & \multirow{4}{*}{ Fair price } & Do you think the price you received is fair? & Ordinal variable $(1-3)$ \\
\hline & & Very fair & 1 \\
\hline & & Not so fair & 2 \\
\hline & & Very unfair & 3 \\
\hline BROKERFEE & Fee paid to brokers & How much do you pay brokers to search for buyers? & Ration variable \\
\hline TIMESPRICE & No. of times price was checked & How many times was the price renegotiated? & Ration variable \\
\hline \multirow{4}{*}{ TIMEBARGAIN } & \multirow{4}{*}{ Times of bargaining } & How much time do you spend negotiating? & Ordinal variable $(1-3)$ \\
\hline & & Very long & 1 \\
\hline & & Not so long & 2 \\
\hline & & Very short & 3 \\
\hline \multirow{3}{*}{ CONTRACT } & \multirow{3}{*}{ Form of sale contract } & Do you sign a formal contract with the buyer? & Dummy variable \\
\hline & & Yes & 1 \\
\hline & & No & 0 \\
\hline \multirow{4}{*}{ CLEARFORM } & \multirow{4}{*}{ Clearing form } & Form of clearing transaction & Ordinal variable $(1-3)$ \\
\hline & & Buyer paid all Cash & 1 \\
\hline & & Buyer partly paid in cash & 2 \\
\hline & & Buyer deferred payment & 3 \\
\hline \multirow{4}{*}{ PAYMENT } & \multirow{4}{*}{ Time to get paid } & When do you get paid? & Ordinal variable $(1-3)$ \\
\hline & & After transaction & 1 \\
\hline & & One week after transaction & 2 \\
\hline & & Default & 3 \\
\hline \multirow{4}{*}{ DEFAULT } & \multirow{4}{*}{ Frequency of default } & How often buyers are in default? & Ordinal variable $(1-3)$ \\
\hline & & Never & 1 \\
\hline & & Occasionally & 2 \\
\hline & & Sometime & 3 \\
\hline
\end{tabular}

PTCs change according to the amount of output traded and are represented by the sales costs, information symmetry, and bargaining power. In this context, the apple producers were asked with three questions: "How much did you pay for storage, packaging, and transportation?"; "Do you know the sale price at another two markets" (which takes the value of 1-3), and "Do you think the price you received is fair" (which takes the value of 1-3).

Information on the transaction can be costly and difficult to obtain. Therefore, the apple producers are asked "How much do you pay brokers to search for buyers?" and "How much time do you spend negotiating?" Time spent on negotiation for an agreement and the form of sale contract are used to represent the negotiation costs. Finally, we consider the monitoring and enforcement costs. A monitoring cost is incurred due to the problem of payment delays and default. The frequencies of payment delay and default, both of which take the value of 1-3, and the clearing form are used to represent the costs of monitoring and enforcement.

\subsection{Market Participation Function Estimation}

To test hypothesis 1 , we first estimate the effect of apple producers' transaction costs for the quantity sold using a semi-log model. The specific model of the smallholders' market participation function is as follows:

$$
\begin{aligned}
& Q=\beta_{0}+\beta{ }_{1} \text { SALECOST }+\beta_{2} \text { MARKETPRIC } E+\beta{ }_{3} \text { FAIRPRICE }+\beta{ }_{4} \text { BROKERFEE } \\
& +\beta \text { STIMESPRICE }+\beta \text { GTIMESBARGA IN }+\beta \text { 7 CONTRACT }+\beta{ }_{8} \text { CLEARFORM } \\
& +\beta{ }_{9} \text { PAYMENT }+\beta{ }_{10} D E F A U L T+\beta{ }_{11} \text { PRICE }+\beta{ }_{12} \text { PLOTSIZE }+\beta{ }_{13} A G E \\
& +\beta{ }_{14 E D U}+\beta{ }_{15} L A B O R+\beta{ }_{16} M E M B E R+\beta{ }_{17} Y E A R+\beta 18 \text { AREA } 2+\beta{ }_{19} \text { AREA } 3 \\
& +\beta_{20} A R E A 4+\beta_{21} A R E A 5+\beta_{22} A R E A 6+\beta_{23} A R E A 7+\varepsilon i
\end{aligned}
$$

The independent variable of this model contains three parts: 1) proportional transaction costs and fixed transaction costs, 2) market price, household characteristics, and 3) a dummy variable of smallholders' living area. The OLS estimation results are presented in Table 6. From the analysis, the household market decision is a 
trade-off between transaction costs and price. Specifically, the quantity sold in the market is mainly determined by the PTCs and the farmer household characteristics. The FTCs have little effect on the dependent variable.

Table 6. OLS regression of household market participation function

\begin{tabular}{|c|c|c|c|c|}
\hline \multirow{2}{*}{$\begin{array}{l}\text { Dependent Variable } \\
\text { Independent Variable }\end{array}$} & \multicolumn{4}{|c|}{ Quantity sold at market (log of quantity) } \\
\hline & Coefficient & Standard Error & $\mathrm{T}$ value & $\mathrm{P}>|\mathrm{T}|$ \\
\hline \multicolumn{5}{|c|}{ Proportional Transaction Costs } \\
\hline SALECOST & $0.0001 * *$ & 0.0001 & 2.27 & 0.024 \\
\hline MARKETPRICE & $0.0840 * * *$ & 0.0303 & 2.77 & 0.006 \\
\hline FAIRPRICE & $-0.1219^{*}$ & 0.0631 & -1.93 & 0.054 \\
\hline \multicolumn{5}{|c|}{ Fixed Transaction Costs } \\
\hline BROKERFEE & $0.0004 * *$ & 0.0001 & 2.78 & 0.006 \\
\hline TIMESPRICE & 0.0089 & 0.0057 & 1.57 & 0.116 \\
\hline TIMEBARGAIN & $0.1289 * *$ & 0.0594 & 2.17 & 0.030 \\
\hline CONTRACT & 0.1228 & 0.0884 & 1.39 & 0.165 \\
\hline CLEARFORM & -0.1047 & 0.0794 & -1.32 & 0.188 \\
\hline PAYMENT & 0.0737 & 0.0523 & 1.41 & 0.159 \\
\hline DEFAULT & -0.0034 & 0.0692 & -0.05 & 0.961 \\
\hline \multicolumn{5}{|l|}{ Market Price } \\
\hline PRICE & $0.3867 * * *$ & 0.0444 & 8.72 & 0.000 \\
\hline \multicolumn{5}{|c|}{ Household Characteristics } \\
\hline PLOTSIZE & $0.0768 * * *$ & 0.0066 & 11.66 & 0.000 \\
\hline AGE & $-0.0076^{* *}$ & 0.0029 & -2.6 & 0.010 \\
\hline EDU & 0.0273 & 0.0377 & 0.72 & 0.469 \\
\hline LABOR & $0.1010 * *$ & 0.0427 & 2.36 & 0.018 \\
\hline MEMBER & $0.1549 * *$ & 0.0616 & 2.51 & 0.012 \\
\hline YEAR & $0.0172 * * *$ & 0.0043 & 3.96 & 0.000 \\
\hline \multicolumn{5}{|l|}{ Zone Dummy } \\
\hline AREA2 & $-0.3284 * * *$ & 0.1133 & -2.9 & 0.004 \\
\hline AREA3 & $0.3413 * * *$ & 0.1207 & 2.83 & 0.005 \\
\hline AREA4 & -0.0767 & 0.1132 & -0.68 & 0.499 \\
\hline AREA5 & 0.0025 & 0.1144 & 0.02 & 0.983 \\
\hline AREA6 & $-0.3981 * * *$ & 0.1173 & -3.39 & 0.001 \\
\hline AREA7 & $-0.4914 * * *$ & 0.1153 & -4.26 & 0.000 \\
\hline Constant & $8.4249 * * *$ & 0.3427 & 24.59 & 0.000 \\
\hline$F$ test & 32.95 & & & \\
\hline Prob $>F$ & 0.000 & & & \\
\hline$R$-square & 0.5481 & & & \\
\hline
\end{tabular}

Note. *,**, and *** indicate significance at 10\%,5\%, and 1\% level, respectively. Sample size: 607 .

The results indicate that the quantity sold at market has a positive reciprocal causal relationship with sale cost (SALECOST) at the 5\% level, and is positively influenced by the accuracy of other markets price (MARKETPRICE), and negatively influenced by the fairness of market price (FAIRPRICE). Market price is found to be significant at the $1 \%$ level in explaining a higher quantity sold. Regarding the households' characteristics, total land coverage dedicated to apple production (PLOTSIZE), the amount of household labor working in apple production (LABOR), membership of cooperatives (MEMBER), as well as years of professional experience have a positive effect on the quantity sold. Age of the household head (Age) has a negative effect. In general, education level does not have much of an impact on the market participation.

\subsection{Market Integration Estimation}

According to the results of section 3, we consider farm-gate, local, and distant markets as degrees of barriers to entry. Therefore, the ordered probit model is applied to estimate the effects of the transaction costs on the apple producers' market integration. The specific function of the model is: 


$$
\begin{aligned}
Y= & \alpha_{0}+\alpha_{1} \text { SALECOST }+\alpha_{2} \text { MARKETPRIC } E+\alpha_{3} \text { FAIRPRICE }+\alpha_{4} \text { BROKERFEE } \\
& \alpha_{5} \text { TIMESPRICE }+\alpha_{6} \text { TIMEBARGAI N }+\alpha_{7} \text { CONTRACT }+\alpha_{8} \text { CLEARFORM } \\
& +\alpha_{9} \text { PAYMENT }+\alpha_{10} \text { DEFAULT }+\alpha_{11} \text { PRICE }+\xi
\end{aligned}
$$

which is usually estimated by maximum likelihood function. Its likelihood function can be written as:

$$
\begin{aligned}
\ln L & =\sum_{i=1}^{n} \sum_{j=1}^{J} y_{i j} \ln \operatorname{Pr}\left(y_{i}=j \mid x_{i}\right) \\
& =\sum_{i=1}^{n} \sum_{j=1}^{J} y_{i j} \ln \left(F\left(\mu_{j}-x_{i} \beta\right)-F\left(\mu_{j-1}-x_{i} \beta\right)\right)
\end{aligned}
$$

Tables 7 and 8 present the regression results estimated by STATA 12.0 and the relative marginal effects of Model (14). The results reveal that the market integration is mainly determined by the FTCs and the price of apples. Negotiation costs, namely time spent negotiating (TIMEBARGAIN) and form of sale contract (CONTRACT)

\begin{tabular}{|c|c|c|c|c|}
\hline \multirow{2}{*}{$\begin{array}{l}\text { Dependent Variable } \\
\text { Independent Variable }\end{array}$} & \multicolumn{4}{|c|}{ Ordinal Choice of Farm-gate, Local, and Distant Markets } \\
\hline & Coefficient & Standard Error & Z-value & $\mathrm{P}>|\mathrm{Z}|$ \\
\hline \multicolumn{5}{|c|}{ Proportional Transaction Costs } \\
\hline SALECOST & 0.0001 & 0.0001 & 1.26 & 0.208 \\
\hline MARKETPRICE & 0.0116 & 0.0570 & 0.2 & 0.839 \\
\hline FAIRPRICE & -0.1707 & 0.1172 & -1.46 & 0.145 \\
\hline \multicolumn{5}{|l|}{ Fixed Transaction Costs } \\
\hline BROKERFEE & 0.0001 & 0.0003 & 0.54 & 0.591 \\
\hline TIMESPRICE & 0.0101 & 0.0108 & 0.93 & 0.353 \\
\hline TIMEBARGAIN & $0.2742 * *$ & 0.1109 & 2.47 & 0.013 \\
\hline CONTRACT & $0.3929 * *$ & 0.1744 & 2.25 & 0.024 \\
\hline CLEARFORM & $-0.5461 * * *$ & 0.1422 & -3.84 & 0.000 \\
\hline PAYMENT & $0.3324 * * *$ & 0.0947 & 3.51 & 0.000 \\
\hline DEFAULT & $-0.2085^{*}$ & 0.1261 & -1.65 & 0.098 \\
\hline \multicolumn{5}{|l|}{ Market Price } \\
\hline PRICE & $-0.1959 * * *$ & 0.0678 & -2.89 & 0.004 \\
\hline Number of obs. & 607 & & & \\
\hline LR Chi2 (11) & 59.74 & & & \\
\hline Prob $>$ Chi 2 & 0.000 & & & \\
\hline Log likelihood & -458.50 & & & \\
\hline Pseudo R2 & 0.061 & & & \\
\hline
\end{tabular}
have a significant effect on market integration, which indicates that the closer apple producers are to the market, the lower the transaction costs and market price received. Regarding enforcement and monitoring costs, if the apple producers are not paid in time and buyer postponed payment or owes money, they prefer closer markets.

Table 7. MLE regression of transaction costs and apple producers' integration

Note. ${ }^{*},{ }^{* *}$, and $* * *$ indicate significance at $10 \%, 5 \%$, and $1 \%$ level, respectively. Sample size: 607. 
Table 8. Marginal effects of transaction costs and market integration from the ordered probit model

\begin{tabular}{|c|c|c|c|c|}
\hline Variable & $\mathrm{dy} / \mathrm{dx}$ & Standard Error & Z-value & $\mathrm{P}>|\mathrm{Z}|$ \\
\hline \multicolumn{5}{|c|}{ Proportional Transaction Costs } \\
\hline SALECOST & 0.0000 & 0.0000 & -1.24 & 0.217 \\
\hline MARKETPRICE & -0.0009 & 0.0044 & -0.2 & 0.839 \\
\hline FAIRPRICE & 0.0130 & 0.0091 & 1.43 & 0.154 \\
\hline \multicolumn{5}{|c|}{ Fixed Transaction Costs } \\
\hline BROKERFEE & 0.0000 & 0.0000 & -0.54 & 0.592 \\
\hline TIMESPRICE & -0.0008 & 0.0008 & -0.92 & 0.357 \\
\hline TIMEBARGAIN & $-0.0209 * *$ & 0.0090 & -2.33 & 0.020 \\
\hline CONTRACT & $-0.0300 * *$ & 0.0139 & -2.16 & 0.031 \\
\hline CLEARFORM & $0.0417 * * *$ & 0.0123 & 3.39 & 0.001 \\
\hline PAYMENT & $-0.0254 * * *$ & 0.0081 & -3.15 & 0.002 \\
\hline DEFAULT & 0.0159 & 0.0099 & 1.61 & 0.108 \\
\hline \multicolumn{5}{|l|}{ Market Price } \\
\hline PRICE & $0.0150 * * *$ & 0.0056 & 2.67 & 0.008 \\
\hline
\end{tabular}

Note. $*, * *$, and $* * *$ indicate significance at $10 \%, 5 \%$, and $1 \%$ level, respectively.

\section{Conclusions and Policy Implications}

Since the Chinese government launched the reform of the agricultural system in 1978, China has established a market-oriented agricultural system. However, China's agricultural market still lacks effectiveness and efficiency due to the lag reform of the farming-land property rights system, the slow development of the specialization and scale of farmers, the weak service functions of independent farmer organizations (e.g., cooperatives), the poor rural and farming infrastructure, and the inefficient regulation system for agricultural markets. Therefore, China's agri-chain arrangements are suffering serious challenges, namely high transaction costs and market risk. Most farmer households face significant market uncertainties without reasonable risk-sharing techniques and mechanisms, which induce new institutional arrangements and organizational innovation. Empirical evidence suggests that smallholder's market integration is a trade-off between the transaction costs and price. Specifically, the levels of farmers' market participation are mainly determined by the PTCs and price, and their market integration depends on the FTCs and price.

We have shown the factors that are most relevant to smallholders' decisions to enter agro-industrial markets. It is the markets that can absorb increasing quantities of apples, providing higher returns to the producers to overcome the transaction costs. Moreover, their farming land scale, labor force size, and the degree of organization have a positive effect on the quantity sold at markets. Therefore, the key constraint factors affecting farm-to-market linkages, the small-land scale, low degree of independent farmers organizations, and and high transaction costs need to be overcome.

As Escobal and Cavero (2012) suggest, with the assistance of an external actor that helps to develop coordination between the small farmers and reduces the transaction costs that affect the farmers more specialization. If Chinese government want to truly level the economic playing field, they may need to improve market environments and reduce the transaction costs smallholders face, in addition to investing and constructing the rural and farm infrastructure, updating the rural information system, and other policies aimed at improving their connections to integrated markets. Moreover, Moreover, the authorities should pay more attentions to perfecting the laws and policies to improve the structure of farmer households. Furthermore, functions of the cooperatives and other independent farmer organizations need to be improved, which will not only increase the likelihood of less endowed smallholders enhancing their opportunities to access integrated markets, but also increase their net incomes.

\section{References}

Alinaghi, N. (2019). Mobile money, risk sharing, and transaction costs: A replication study of evidence from Kenya's mobile money revolution. Journal of Development Effectiveness, 11(4), 342-359. https://doi.org/ $10.1080 / 19439342.2019 .1684343$

Burciu, A., \& Kicsi, R. (2016). Rethinking the Nature of Firm: New Paradigms. Innovation Management and Education Excellence Vision 2020: From Regional Development Sustainability to Global Economic Growth, I-Vi, 179-188. 
Carter, R., \& Hodgson, G. M. (2006). The impact of empirical tests of transaction cost economics on the debate on the nature of the firm. Strategic Management Journal, 27(5), 461-476. https://doi.org/10.1002/smj.531

Dimitri, C., \& Gardner, K. (2019). Farmer use of intermediated market channels: a review. Renewable Agriculture and Food Systems, 34(3), 181-197. https://doi.org/10.1017/S1742170518000182

Escobal, J. A., \& Cavero, D. (2012). Transaction Costs, Institutional Arrangements and Inequality Outcomes: Potato Marketing by Small Producers in Rural Peru. World Development, 40(2), 329-341. https://doi.org/ 10.1016/j.worlddev.2011.07.016

Filomena, T. P., \& Lejeune, M. A. (2014). Warm-Start Heuristic for Stochastic Portfolio Optimization with Fixed and Proportional Transaction Costs. Journal of Optimization Theory and Applications, 161(1), 308-329. https://doi.org/10.1007/s10957-013-0348-y

Hou, J. Y., Huo, X. X., \& Yin, R. S. (2017). Land Rental Market Participation and Its Impact on Fixed Investment and Household Welfare: Evidence from Chinese Apple Production Sites. Sustainability, 9(11). https://doi.org/10.3390/su9111961

Hou, J. Y., Huo, X. X., \& Yin, R. S. (2019). Does computer usage change farmers' production and consumption? Evidence from China. China Agricultural Economic Review, 11(2), 387-410. https://doi.org/10.1108/ CAER-09-2016-0149

Leger-Bosch, C. (2019). Farmland tenure and transaction costs: Public and collectively owned land vs conventional coordination mechanisms in France. Canadian Journal of Agricultural Economics-Revue Canadienne D Agroeconomie, 67(3), 283-301. https://doi.org/10.1111/cjag.12206

Negi, D. S., Birthal, P. S., Roy, D., \& Khan, M. T. (2018). Farmers' choice of market channels and producer prices in India: Role of transportation and communication networks. Food Policy, 81, 106-121. https://doi.org/10.1016/j.foodpol.2018.10.008

Xu, D., \& Long, Y. (2020). The role of supply chain integration in the transformation of food manufacturers: A case study from China. International Journal of Logistics-Research and Applications. https://doi.org/ $10.1080 / 13675567.2020 .1729707$

Zanello, G., Srinivasan, C. S., \& Shankar, B. (2014). Transaction Costs, Information Technologies, and the Choice of Marketplace among Farmers in Northern Ghana. Journal of Development Studies, 50(9), 1226-1239. https://doi.org/10.1080/00220388.2014.903244

Zant, W. (2018). Trains, Trade, and Transaction Costs: How Does Domestic Trade by Rail Affect Market Prices of Malawi Agricultural Commodities? World Bank Economic Review, 32(2), 334-356. https://doi.org/ 10.1093/wber/lhx011

\section{Copyrights}

Copyright for this article is retained by the author(s), with first publication rights granted to the journal.

This is an open-access article distributed under the terms and conditions of the Creative Commons Attribution license (http://creativecommons.org/licenses/by/4.0/). 